\title{
Fumigating the Hygienic Model City: Bubonic Plague and the Sulfurozador in Early-Twentieth-Century Buenos Aires
}

\author{
LUKAS ENGELMANN * \\ University of Edinburgh, STIS, 2.01 Old Surgeon's Hall, High School Yards, Edinburgh, \\ EH1 1LZ, UK
}

\begin{abstract}
The 1899/1900 arrival of bubonic plague in Argentina had thrown the model status of Buenos Aires as a hygienic city into crisis. Where the idea of foreign threats and imported epidemics had dominated the thinking of Argentina's sanitarians at that time, plague renewed concerns about hidden threats within the fabric of the capital's dense environment; concerns that led to new sanitary measures and unprecedented rat-campaigns supported by the large-scale application of sulphur dioxide. The article tells the story of early twentieth-century urban sanitation in Buenos Aires through the lens of a new industrial disinfection apparatus. The Aparato Marot, also known as Sulfurozador was acquired and integrated in the capital's sanitary administration by the epidemiologist José Penna in 1906 to materialise two key lessons learned from plague. First, the machine was supposed to translate the successful disinfection practices of global maritime sanitation into urban epidemic control in Argentina. Second, the machine's design enabled public health authorities to reinvigorate a traditional hygienic concern for the entirety of the city's terrain. While the Sulfurozador offered effective destruction of rats, it promised also a comprehensive - and utopian - disinfection of the whole city, freeing it from all imaginable pathogens, insects as well as rodents. In 1910, the successful introduction of the Sulfurozador encouraged Argentina's medico-political elite to introduce a new principle of 'general prophylaxis'. This article places the apparatus as a technological modernisation of traditional sanitary practices in the bacteriological age, which preserved the urban
\end{abstract}

* Author line: Lukas Engelmann is a historian of medicine and a Chancellor's Fellow at the University of Edinburgh in Science, Technology and Innovation Studies. Email address for correspondence:

Lukas.engelmann@ed.ac.uk

This paper has come out of an enriching collaboration on the history of maritime sanitation with Christos Lynteris, to whom I owe many thanks. I am indebted to Kate Womersley for her critical review of the story told on the following pages. Furthermore, I'd like to thank Jacob Steere-Williams for enabling the paper's first public appearance at the AAHM 2017, Steve Sturdy for encouraging feedback on an early version and Arlene Shaner and the New York Academy of Medicine for their generous support. Finally, I like to express my gratitude to the generosity of the anonymous reviewers and the time they have dedicated to this article. The research leading to these results has received funding from the European Research Council under the European Union's Seventh Framework Programme (FP7/2007-2013)/ERC grant agreement number 336564. 
environment - 'el terreno' - as a principal site of intervention. Thus, the Sulfurozador allowed the 'higienistas' to sustain a long-standing utopian vision of all-encompassing social, bodily and political hygiene into the twentieth century.

Keywords: Buenos Aires, Public Health, Prevention, Disinfection, Bubonic Plague, Fumigation

\section{Introduction}

For Argentina's powerful medico-political elite - the 'higienistas' - the turn of the twentieth century was a time of enthusiastic innovation, rapid progress and growing hope to lay the foundation for a robust and healthy future for the young nation. Among the architects of this modernised utopian vision for a sanitary state was José Penna, a prominent physician who held the country's first academic chair of epidemiology in 1900. When he was tasked with controlling the capital's public health service in 1906, his most prestigious acquisition was a disinfection machine: the Aparato Marot. Invented in 1904 in France, six of these machines were imported and installed on horse carriages and automobiles to carry out comprehensive disinfection of homes, warehouses, streets and the city's new sewage system. Eventually, as the rat became the health authority's key adversary, the machine's immense capacity enabled a comprehensive sanitation campaign, aimed ambitiously to disinfect and to disinfest the entirety of the terrain of Buenos Aires.

The apparatus yielded outstanding results. By injecting sulphur dioxide into enclosed buildings, both residential and commercial spaces could quickly be freed of possible sources of infection. The Marot came equipped with an additional innovative component. The device electrified the sulphur dioxide before propelling it out of the pipes, which created an ozone effect, resulting in a lighter gas. Thus, the gas could easily fill large rooms without extensive isolation, killing pathogens, insects and rodents throughout the space. It was especially effective in annihilating rats often found climbing the beams of buildings to escape the lethal fumes. The machine, placed at the heart of Penna's ambitious scientific urban sanitation programme, quickly became known to Argentinians as the Sulfurozador.

This local history of the Sulfurozador's relation to the twentieth-century hygienic vision of Buenos Aires illuminates and exemplifies a larger transnational, perhaps global, push to establish rigorous and scientifically proven sanitation methods. ${ }^{1}$ Across Latin America, hygiene was seen as a driver for social change, public health programmes had achieved a prominent status in late nineteenth-century state-building processes, combining urbanisation, centralisation and the negotiation of individual rights within the public sphere. The national identities of Argentina, Peru, Brazil and many other thriving nations was strongly influenced - as Marcos Cueto and Steven Palmer have recently discussed in detail - by the installation of institutions devoted to national health. ${ }^{2}$ Routines, laws and a morality of hygiene were adapted as 'means of articulating political concerns in technical terms', both on national and (towards the end of the nineteenth century)

${ }^{1}$ As a history pertinent to the peculiar space of urban modernity that developed in Buenos Aires at the turn of the twentieth century, this local case requires also differentiation from health transformation affecting the nation of Argentina and very different trajectories experienced at the same time in rural communities. See María Silvia Di Liscia, 'Del brazo civilizador a la defensa nacional: políticas sanitarias, atención médica y población rural (Argentina, 1900-30)', Historia Caribe, 12, 31 (2017), 159-93.

${ }^{2}$ Marcos Cueto and Steven Palmer, Medicine and Public Health in Latin America (Cambridge: Cambridge University Press, 2014), 13. 
on transnational levels. ${ }^{3}$ Nation-building and the emergence of a field of state-governed medicine were, as José Amador has argued, deeply intertwined: 'public health transformed more than ideas about disease', he writes. '[I]t entered public consciousness to shape attitudes about race, plantation life, urbanization, spaces of sociability, and personal responsibility. ${ }^{4}$

At the end of the nineteenth century, fumigation with sulphur dioxide had become a central pillar of global as well as Latin American maritime sanitation. On the heels of a devastating cholera outbreak in 1886, an agreement was signed by Brazil, Uruguay and Argentina in 1887, later joined by Paraguay, to establish sanitary conventions in all major South American ports. ${ }^{5}$ A transnational scientific commission strongly recommended widespread fumigation of vessels with sulphur dioxide to re-establish trust in the trade connections across borders. ${ }^{6}$ But it would take until the beginning of the twentieth century, and the arrival of bubonic plague in Latin America, for a new urgency for sanitary hygiene to be met with industrial and technological innovation. ${ }^{7}$ Across the continent - as well as in many other ports across the world - advanced fumigation machines such as the Clayton apparatus or the Aparato Marot were put in place to curb the transmission of yellow fever, typhoid fever, cholera and bubonic plague on the pathways of maritime commerce. But occasionally, as in Buenos Aires, but also in Rio de Janeiro, New Orleans and San Francisco, these machines were brought into the streets to enable extensive disinfection campaigns with sulphur dioxide in the urban environment.

However, only in Buenos Aires has the introduction of a disinfection machine to the streets and homes of its residents led to the resurgence of a utopian vision of total urban disinfection. I ask here if and to what extent this vision was encapsulated in and catalysed by the technological capacities of the Sulfurozador. Many scholars have addressed Argentina's hygienic movement between 1880 and 1910 as a characteristic social and political foundation of public health in Latin America. But while the motives, traditions and discourses of the 'higienistas' have received much scholarly attention, their successful practices, and the material changes their visions brought about, remain at times overshadowed. ${ }^{8}$ Questions remain about how utopian visions of a hygienic future were implemented on Argentina's 'epidemic streets' and how the expansive system of prevention policies that would come to characterise twentieth-century Buenos

\footnotetext{
${ }^{3}$ Diego Armus, 'Disease in the historiography of modern Latin America', in Diego Armus (ed.), Disease in the History of Modern Latin America: From Malaria to AIDS (Durham, NC: Duke University Press, 2003), 13; Marcos Cueto, The Value of Health: A History of the Pan American Health Organization (Washington DC: Pan American Health Organization, 2007).

${ }^{4}$ José Amador, Medicine and Nation Building in the Americas, 1890-1940 (Nashville: Vanderbilt University Press, 2015), 5.

5 J. Guilherme Lacorte, 'A Atuação de Oswaldo Cruz no aparecimento da Peste Bubonica no Brasil', A Folha Medica, 54 (1967), 183-8.

${ }^{6}$ Fernanda Rebelo, 'Between the Carlo R. and the Orleannais: Public Health and Maritime Prophylaxis in the Description of Two Cases of Ships Transporting Immigrants Arriving in the Port of Rio de Janeiro, 1893-1907', História, Ciências, Saúde-Manguinhos, 20, 3 (2013), 12.

7 Jaime Larry Benchimol, Dos Micróbios aos Mosquitos: Febre Amarela e a Revolução Pasteuriana no Brasil (Rio de Janeiro: SciELO - Editora FIOCRUZ, 1999), $259 \mathrm{ff}$.

${ }^{8}$ Alejandro Kohl, Higienismo Argentino: Historia de una Utopía. La salud en el Imaginario Colectivo de una Época (Buenos Aires: Editorial Dunken, 2006); Kristin Ruggiero, Modernity in the Flesh: Medicine, Law, and Society in Turn-of-the-Century Argentina (Stanford: Stanford University Press, 2004); Norma Isabel Sánchez and Alfredo G. Kohn Loncarica, La Higiene y los Higienistas en la Argentina: 1880-1943 (Buenos Aires: Sociedad Científica Argentina, 2007).
} 
Aires were materialised. ${ }^{9}$ As this history is also marked by significant epistemological transformations, I ask here how the 'intrusive interventions' of sanitary brigades were modernised and industrialised to transfer the hygienic utopia of the Argentinian capital into the twentieth century. ${ }^{10}$

In 1906, the Marot crowned a long series of innovative sanitary improvements of Buenos Aires, of which the most significant was the introduction of sanitary brigades. As Adriana Alvarez and Susana Belmartino have argued, systematic centralisation and institutionalisation in Argentina's health administration encouraged rapid introduction of modern methods. ${ }^{11}$ After the national Department of Hygiene was founded in 1880, followed by the Asistencia Pública [public service] in 1883, the city saw the first disinfection brigades operating on the streets by 1888. As Alvarez emphasises, the purpose of the brigades and their intrusive campaigns was not only to disinfect 'pathogenic' houses, but also to demonstrate the impotence of traditional methods, which relied on old theories about miasma, still practiced mostly in private. ${ }^{12}$ Moreover, Diego Armus has argued that the disinfection brigades effectively mobilised bacteriology to overtake miasmatic theories of infection, marking how this new science left the spaces of laboratories and hospitals to be used in a public and visible way. ${ }^{13}$

It was the arrival of bubonic plague in 1899/1900 that exposed the failure of existing sanitary strategies and concepts. ${ }^{14}$ The outbreak led to a renewed push for improvement of the city's hygienic state and, as the rat moved to the centre of sanitary campaigns, it encouraged a renewed sense of the city's environment as an infected terrain. In the aftermath of plague, the Aparato Marot came to stand for two decisive transformations in the fight against infectious diseases in Buenos Aires from 1906 onwards. Firstly, its application in streets and houses symbolised a shift in the consideration of the origin of epidemics as the Sulfurozador should protect the urban environment against infectious diseases that were increasingly seen as endemic threats from within. Secondly, the Sulfurozador was key to the modernisation of a long-standing innovative public health

\footnotetext{
${ }^{9}$ Anne Hardy, The Epidemic Streets: Infectious Disease and the Rise of Preventive Medicine, 1856-1900 (Wotton-under-Edge: Clarendon Press, 1993). Diego Armus, 'Utopias Higienicas/Utopias Urbanas. Buenos Aires 1920', in Heffes, Gisela (ed.), Utopias Urbanas: Geopoliticos Del Deseo En America Latina (Frankfurt/Madrid: Verveurt, 2013), 115-30.

${ }^{10}$ Graham Mooney, Intrusive Interventions: Public Health, Domestic Space and Infectious Disease Surveillance in England, 1840-1914 (Woodbridge: Boydell \& Brewer, 2015).

11 Adriana Alvarez, 'Resignificando Los Conceptos de La Higiene: El Surgimiento de una Autoridad Sanitaria en el Buenos Aires de los Años 80', História, Ciências, Saúde-Manguinhos, 6, 2 (1999), 293-314; Susana Belmartino, La atención médica argentina en el siglo XX: instituciones y procesos (Buenos Aires: Siglo Veintiuno Editores Argentina, 2005).

12 Alvarez, ibid., 299.

${ }^{13}$ Many scholars have emphasised that the modernisation of Buenos Aires, and especially of the impoverished parts of the capital, saw fear of infection, unhygienic living conditions and the state of morality addressed as deeply associated issues. See: Diego Armus, 'El Descubrimiento de La Enfermedad Como Problem Social', in Mirta Zaida Lobato (ed.), El Progreso, La Modernización y Sus Límites (1880-1916) (Buenos Aires: Editorial Sudamericana, 2002), 515; Alvarez, op. cit. (note 11); Belmartino, op. cit. (note 11); Adriana Alvarez and Adrián Carbonetti, Saberes y prácticas médicas en la Argentina: un recorrido por historias de vida (Buenos Aires: EUDEM, 2008); Diego Armus, The Ailing City: Health, Tuberculosis, and Culture in Buenos Aires, 1870-1950 (Durham, NC: Duke University Press, 2011); Kindon Thomas Meik, 'Disease and Hygiene in the Construction of a Nation: The Public Sphere, Public Space, and the Private Domain in Buenos Aires, 1871-1910'(unpublished $\mathrm{PhD}$ thesis: Florida International University, 2011).

${ }^{14}$ Luis Agote and A.J. Medina, La Peste Bubonique dans la République Argentine et au Paraguay: Épidémies de 1899-1900 (Buenos Aires: F. Lajouane, 1901); Myron J. Echenberg, Plague Ports: The Global Urban Impact of Bubonic Plague, 1894-1901 (New York: New York University Press, 2007).
} 
tradition, rooted in Guillermo Rawson's 1870s utopian vision of a sanitary state at the southern tip of Latin America.

The city's terrain, its streets, houses, sewage systems and open land had once been the exclusive focus of old sanitarians' attention. With the Aparato Marot, I argue, this terrain became subjected to modernised, sophisticated and experimentally proven disinfection. The machine mobilised maritime fumigation beyond the port to renew the visionary and popular poetics of a 'Higienismo Argentino' during a period of growing positivism and rationalism. ${ }^{15}$ Alejandro Kohl has described these utopian poetics to be drivers of the original hygienic programme of the sanitarians Rawson and Wilde. They had merged since the 1870 s the vision of an ideal society with campaigns to remove miasma, foul stench and noxious vapours. ${ }^{16}$ This legacy of 'civic health' was translated now into a modern principle of 'general prophylaxis'. The integration of the new technology in 1906 symbolised the successful adaptation of traditional sanitary practices within the epistemological environment of modern bacteriology and laboratory science. I demonstrate on the following pages how, in technological descriptions of the machine, in the experimental evaluation of its capacities and in the admiration for its all-encompassing disinfection qualities, a sense of the utopian visions of the old sanitarians was captured and renewed to envision a new sense of hygienic invulnerability.

With reference to Ernst Bloch, this utopia should be understood within the broader field of 'concrete utopia'; in other words, a 'transformed future' which, however elusive, was practically and materially sought. ${ }^{17}$ Following Ruth Levitas' analysis of Bloch's work, this is a type of utopia based on reaching 'forward to a real possible future, and involves not merely wishful but will-full thinking'. ${ }^{18}$ It is a utopia that reaches towards such a future and anticipates it; it projects the vision of a hygienic city and catalyses the introduction and application of practices that not only improve the city's sanitary state, but embody the very possibility of a hygienic urban space. The Sulfurozador did not merely feed into the poetics of the traditional Argentinian hygienic vision; it instantiated and materialised the utopia of a city free from diseases by promising enduring safety, or what the Argentinian government would eventually call a 'general prophylaxis'. The mobile disinfection machines established an image of lasting immunity against any infection, especially among the urban breeding-grounds for epidemic, epitomised in the campaigns against rats after 1906. Furthermore, the machine's spectacular appearance, captured in many photographs, embossed the image of the state's capable and appropriate intervention into the fabric of city life. ${ }^{19}$

I begin with a short overview of the hygienic movement of Argentina and the efforts undertaken to transform Buenos Aires into a model hygienic city since 1870. Then I illuminate the emergence and institutionalisation of disinfection practices and focus on the conceptual integration of bacteriological perspectives into Argentina's epidemiology.

\footnotetext{
15 Kohl, op. cit. (note 8).

${ }^{16}$ Ibid., 45.

${ }^{17}$ Ernst Bloch, The Principle of Hope (Cambridge, MA: MIT Press, 1995).

18 Ruth Levitas, 'Educated Hope: Ernst Bloch on Abstract and Concrete Utopia', Utopian Studies, 1, 2 (1990), 14.

${ }^{19}$ One of the many photographs of the Aparato Marot in Buenos Aires is included in the paper (see Figure 3), despite the fact that it's archival provenance remains vague and there are currently no further indicators as to the circumstances under which pictures like this have been taken, what they were used for and to what kind of reception they were exposed. However, they serve as a support for the tangential argument that the machines were a spectacular demonstration of the authority's efforts to sanitise the city.
} 
The subsequent section shows how the unexpected outbreak of bubonic plague in Buenos Aires fuelled the rapid development of novel strategies for sanitation, and foregrounds the rat as a new adversary for public health intervention. I then turn to the Aparato Marot, it's descriptions, critical and experimental appraisal and its elevation into a spearhead of the newly-popular promise of 'general prophylaxis'. I follow Penna, the key figure behind the introduction of the Marot, as he set up experiments to determine the capacity of these machines, the density of the chemical solutions required and the manual routines needed to achieve complete eradications of germs, insects and any potential animal vectors of disease, before I close with the celebration of the machine's triumph by his successors. ${ }^{20}$

\section{Making Buenos Aires the Hygienic Model City}

Since the 1870s, Buenos Aires had experienced unexpected growth, which, according to Kohl, contributed to the city's newfound status as a laboratory for social and political visions. A new emerging 'poetics of wellbeing' found immediate application in urban planning. The question was how to devise conditions of social life that would allow the population to conserve its health, keeping infectious diseases from entering the capital, while crafting a vision of the ideal state. ${ }^{21}$ But the extensive programmes, designed to secure the capital's hygienic status also required rigorous sanitary policing.

Since the end of the Argentinian civil war in 1880, Argentina had seen the rise of a medico-political elite dedicated to hygienic reinvention of the young Latin American nation. Throughout the second half of the nineteenth century, a repeating cycle of cholera and yellow fever epidemics had brought about the emergence of the 'higienistas', a powerful group of doctors and public health proponents who merged issues of social and cultural progress with the installation of public health infrastructures. With ambitious programmes that aimed for heightened standards of household cleanliness, these doctors appealed to a new sense of hygienic citizenship, in which the value of liberalism was joined to strict marital ideals, moral regimes and utopian visions of public health. ${ }^{22}$ To extend 'modernity into the flesh' of Argentinian citizens, Ruggiero writes, new laws, regulations and unprecedented campaigns were devised that relied on intrusive inspection. ${ }^{23}$ With the installation of large parks, the construction of a sewage system and the reorganisation of garbage disposal, traditional sanitarians were keen to intervene into private spaces. Instructions for cleanliness in the private home were essential instruments for engineering social change. ${ }^{24}$

The extraordinary programme of the 'higienistas' for sanitary utopianism has often been attributed to the nation's father of public health, Guillermo Rawson. He founded Argentina's first board of health, the 'consejo de higiene pública', in 1852, which was built to resemble European and North American models as a body of independent expertise. Rawson laid the groundwork for an emerging class of a medical elite. Among them was Eduardo Wilde, who had joined forces with Rawson at the university's hygiene department, and who took over the capital's waterworks and sanitation commission

${ }^{20}$ José Penna, La Administración Sanitaria y Asistencia Pública de la Ciudad de Buenos Aires (Buenos Aires: Imp. G. Kraft, 1910).

${ }^{21}$ Kohl, op. cit. (note 8), 44.

22 Armus, op. cit. (note 13).

${ }^{23}$ Ruggiero, op. cit. (note 8).

24 Julia Rodríguez, Civilizing Argentina: Science, Medicine, and the Modern State (Chapel Hill: University of North Carolina Press, 2006). 
in $1880 .{ }^{25}$ A strong believer in the promise of sanitary reforms, Wilde continued to improve the capital's cleanliness to bolster its defence against the entry of diseases. ${ }^{26}$ The early 'higienistas' shared a belief in miasmatic concepts. Accordingly, their popular reforms required a shared responsibility, far exceeding that of physicians, for the hygienic protection of the urban space in its entirety.

In 1880, the board of health was replaced by the national Department of Hygiene. Responsibility for the sanitation of Buenos Aires was assigned to the Asistencia Pública in 1883. Inspections, reporting and control was carried out by its executive arm, the sanitary administration, initially led by Drs Carlos Malbrán and Antonio Gandolfo. With this institutionalisation of an ambitious hygienic programme, prevention strategies and prophylaxis were formalised and became enshrined into state doctrine. ${ }^{27}$ The Asistencia Pública became responsible for the registration and surveillance of all infectious disease cases. $^{28}$ Its executive arm carried out public work projects such as installing running water and a new sewage system, as well as assuming control of hospitals. But it also became responsible for overseeing wet nurses, vaccination programmes, transportation of cadavers and the regulation of prostitution. Public sanitary initiatives, like encouragement to improve hygienic bathroom practices and install modern toilets, were at the time driven by what Ruggiero describes as a 'moral contagion'. ${ }^{29}$

The impact of the 'higienistas' started to flourish when 'the state committed expanding resources to public health campaigns against epidemics, which in turn provided a model for similar public-private collaboration in the sphere of social hygiene'. ${ }^{30}$ Wilde had installed a system of hygienic inspections for poor housing with regular visits every two months. ${ }^{31}$ He had remained sceptical of the ongoing bacteriological transformation of public health, and much of his enthusiasm for structural sanitary reforms in the sewage system and in private households sprung from his belief in the spontaneous production of epidemics through contaminated conditions such as noxious gases from latrines. ${ }^{32}$ Among his most prestigious projects was the establishment of parks and preserving green areas in the capital to safeguard its 'reservoirs of pure air'. ${ }^{33}$ Wilde's public health programme 'deemed the city an artefact and social fabric in which fear of contagion, the morality and living conditions of the urban masses, and concerns about faulty city infrastructure were closely associated'. ${ }^{34}$ Medicine did not only encourage to see the urban society as a malleable organism, but doctors took on the role of social engineers. ${ }^{35}$ The historian Echenberg considered the medical elites around Wilde to be driven by a simplified Darwinism, installing a discourse of hygienic improvement with roots in Neo-Lamarckian ideas of heredity. Improving the nation's health was thus supposed to raise moral, racial and physical purity. ${ }^{36}$

${ }^{25} \mathrm{Ibid} ., 41$.

${ }^{26}$ Meik, op. cit. (note 13), 25.

${ }^{27}$ Alvarez and Carbonetti, op. cit. (note 13), 62.

${ }^{28}$ Cueto and Palmer, op. cit. (note 2), 76.

${ }^{29}$ Ruggiero, op. cit. (note 8), 90.

${ }^{30}$ Rodríguez, op. cit. (note 24), 42.

${ }^{31}$ Ibid., 183 .

32 Ruggiero, op. cit. (note 8), $87 \mathrm{ff}$.

${ }^{33}$ Meik, op. cit. (note 13), 111.

${ }^{34}$ Armus, op. cit. (note 13), 119.

${ }^{35}$ Armus, op.cit. (note 9), 116.

${ }^{36}$ Echenberg, op. cit. (note 14), 136. 
Wilde's replacement at the Asistencia Pública in 1900 was Carlos Malbrán, a bacteriologist schooled in Europe and a firm believer in germ theory and in the necessity for scientific responses to epidemic threats. After a steep career in the medical institutions of Argentina, his appointment was paradigmatic for the arrival of laboratory science in the public health architecture of Buenos Aires. Malbrán's epidemiological views centred on the microbe, and his policies focused on its containment both at the port and in the urban landscape. His heritage, enshrined today in the nation's bacteriological research institute, the Instituto Dr Carlos Malbrán, was continued in 1906 by José Penna, then the doyen of Argentinian bacteriology. After Penna was promoted into the country's first chair of epidemiology in 1900, he became known as a fierce opponent of the anti-contagionist sentiments of Wilde and Rawson. But despite the strong scientific programme from Malbrán and Penna, both remained dedicated to the improvement of the city's political, social and moral constitution by means of prevention and prophylaxis.

\section{José Penna and the Bacteriological Renewal of 'Higienismo Argentino'}

As he looked back in his 1910 report, Penna placed the establishment of large-scale urban fumigation at the logical end of a history of rigorous surveillance and intrusive disinfection, structured by technological advancements since the late 1880s. As a modern epidemiologist, Penna condemned the intellectual foundations of Wilde's sanitary legacy, but applauded many of his initiatives that had improved the nation's hygiene. Kohl suggests that, by perpetuating the popular legacy of Rawson and Wilde, Penna's brand of epidemiology successfully merged the utopian visions and idealising language of the old sanitarians with the new laboratory science and modern principles of prophylaxis. ${ }^{37}$ Accordingly, Penna celebrated some of the established instruments of Rawson and Wilde, such as hygienic education, and particularly emphasised the significance of central civil registries.

For Penna, the registries had been a key advancement to track the success as well as failure of public health measures implemented since the $1880 \mathrm{~s}$. The civil registries revealed a general reduction in the city's mortality rate over the $1880 \mathrm{~s}$ and $1890 \mathrm{~s}$. While the population almost doubled between 1888 and 1899 (from 455167 to 795323 ), the general annual mortality only grew from 12.367 to 13.567 , which caused a considerable drop from $27.17 \%$ to $17 \%{ }^{38}$ Despite this success, infectious diseases remained the cause of death in almost half of the cases throughout that period. While Penna applauded the positive impact of Wilde's reforms, he saw the continuously high death rates due to infectious diseases as an embarrassment for the sanitary state of the capital. 'It should not be forgotten', he wrote in 1910, 'that these are diseases that by their very nature can be reduced or even prevented, some of them completely, with the reasoned application of modes of prophylaxis. ${ }^{39}$

Penna explained his epidemiological views further: infectious diseases could be defeated in two ways. First, to establish an individual state of vigorous health, he advised the populous should eat adequate nutritious food, to avoid excess of all kinds and to distribute vaccines for diseases such as smallpox; but, second, the health administration had to develop systematic approaches to destroy disease vectors and exterminate pathogens from their hiding places throughout the city. ${ }^{40}$ Isolation and quarantine of patients in pest

${ }^{37}$ Kohl, op. cit. (note 8), 72.

38 Penna, op. cit. (note 20), 55.

${ }^{39} \mathrm{Ibid}$. [All quotes from Penna in this article are the author's translation.]

${ }^{40}$ Ibid., 92. 
houses had only limited effects, as it emerged in 1900 that animals such as rats might be indeed responsible for disseminating diseases-causing agents across the city. Penna concluded therefore, that ' $[\mathrm{t}] \mathrm{h}$ e disinfection of places, clothes and objects that the patient might have contaminated, are central measures of prophylaxis' ${ }^{41}$

In turn-of-the-century Argentina, after Wilde's departure, 'the microbe' was the new symbolic and practical target of prophylaxis. Miasmatic theories were then dismissed as irrelevant pre-modern conceptions of disease causality. But early bacteriology in Argentina never fully endorsed an autarchy of the laboratory. Microbes were seen by the country's most eminent epidemiologist as only one of two indispensable factors: the cause of an infectious disease could equally be attributed to the conditions that allow the microbe to flourish. Importantly, this ecology of disease pointed far beyond the constitution of the human body. Where Worboys has modulated the historical narrative of the supposed bacteriological revolution as one that emphasised the relationship of the human 'soil' and the bacteriological 'seed', Penna's convictions integrated the environment in its entirety as a consideration of a modern, scientific reinvention of traditional hygienic practices in Argentina. ${ }^{42}$

But this appreciation of urban ecology in terms of bacteriological science did not contrary to the perspective of Latour for the 'Pasteurization of France' - bring about a sharper focus on sanitary intervention. ${ }^{43}$ Instead, Penna's pragmatic approach to microbes and their environment was characterised by the fact that knowledge about animal vectors and the implication of soil, merchandise and furniture in the transmission of infectious diseases remained an object of heated speculation. He admits freely that 'the aetiological foundations for the advised disinfection procedures are at present not fully known' ${ }^{44}$

To Penna, the vital factor to prevent infectious diseases was 'el terreno', the terrain. ${ }^{45}$ This was where the microbe cultivated itself and through which it manifested its properties, and, most importantly, it was the breeding ground of rats. Without a systematic consideration of soil, walls and ceilings as well as fabrics, grains, fruits and vegetables, Penna considered the fight against infectious disease to be futile. If one were aiming to destroy pathogens, the real aim of public health measures was to remove every possible condition under which the pathogen could survive outside the human body. But, given widespread uncertainty about the relationship between microbes and their material environments, Penna conceded by 1910 that the sanitary fantasy of complete destruction of the conditions for microbes to survive would remain a utopia - at least for the foreseeable future. ${ }^{46}$ It is important to note here that ambiguity about specific vectors underpinned Penna's epidemiological understanding of the terrain as a broadly defined space in which bacteria was nesting and in which transmission could happen. Uncertainty about aetiologies and modes of transmission motivated Penna's improvement and expansion of a disinfection programme that would destruct any plausible vector and destroy bacteria as much as insects and rats.

Established in the early 1880 s, a steadily growing body of brigades had been responsible for the inspection and control of hygienic standards in food production, but also to improve

${ }^{41}$ Ibid., 94.

${ }^{42}$ Michael Worboys, Spreading Germs: Disease Theories and Medical Practice in Britain, 1865-1900 (Cambridge, UK: Cambridge University Press, 2000).

${ }^{43}$ Bruno Latour, The Pasteurization of France (Cambridge, MA: Harvard University Press, 1988).

${ }^{44}$ Penna, op. cit. (note 20), 165.

${ }^{45}$ Ibid., 95.

${ }^{46}$ Ibid. 
the general hygienic appearance of the city, both on the streets as well as in private homes and industrial sites. The fight against contagions required, so Armus writes, new forms of social control and implied new practices of socialisation in which humanitarian efforts were often met by strict sanitary enforcements. ${ }^{47}$ As cleanliness and its restrictive - at times, intrusive - implementation became a cornerstone of the capital's self-perception, sanitary brigades became an iconic representation of the state's efforts to police its hygienic status. Through the politics of the brigades, Rodríguez argues, health came to be seen as the supreme law of the state, and hygiene the appropriate tool for forging necessary social change to prevent epidemics from both arriving and thriving. ${ }^{48}$ Infections that appeared in spite of such extensive measure were often attributed to social degeneration, racial impurity and the subsequent reversal of 'Europeanisation'.

In 1888, the rapidly growing Asistencia Pública invested in the orderly installation of a disinfection brigade, the 'Cuerpo de Disinfectadores', to act in rapid response to cases of disease reported by inspectors or suspicions raised by citizens. ${ }^{49}$ Upon the initiative of Ramos Meija, disinfection campaigns were thought to bring the benefits of bacteriology to the houses and streets in which cases of infectious disease had been observed. Throughout the $1890 \mathrm{~s}$, this procedure became a guarantor of safety and was widely thought reliable. From 1893 onwards, restrictive laws and strong legislative capacities gave sanitary forces invasive access into the fabric of Argentina's society. Sanitary police corps secured the city at the turn of the century in its port, its production facilities, its graveyards and food facilities. ${ }^{50}$ Penna saw the brigades as decisive factor for the slightly decreasing numbers of infectious disease and he attributed their success to a seamless system of inspection and subsequent disinfection. He demonstrated his conceptual admiration of the brigade's work in a detailed diagram. A scheme of the standard procedure of disinfection offers a good impression of the meticulous order with which a property was returned to safety after an outbreak (see Figure 1).

After a disease was reported, a series of forms, reports and surveillance notes were gathered in the office of the sanitary administration and an officer (usually a physician) was sent to the building in which the case of an infectious disease had been reported, to make assessments regarding the general hygienic state of the building, its interior and its water facilities. Another officer would go to the nearest disinfection station to instruct the crew about the case, so that they could ready one of the prestigious Geneste-Herscher disinfection steamers. Meik describes the procedures that followed:

Disinfection teams arrived wearing a special suit provided by the administration. The suit completely covered the clothing of the employee and the head was to be covered by a cloth hat. Hair and beards were to be trimmed short. Prior to entering the home, the team disinfected the soles of their boots in a bichloride mercury solution. Once in the home, the team removed any contaminated clothing, bedding, and household items that could be placed in a vapour humidifying stove to be cleansed. ${ }^{51}$

The crew would then gather all infected materials, mostly fabrics - such as clothes, leathers and linen - and transport them to the disinfection station where they were exposed to large volumes of steam, and then returned in a sterilised state. ${ }^{52}$ This protocol foregrounded the urban places of infection and moved the private environment, in which microbes might lurk, to the fore of prevention practices.

\footnotetext{
${ }^{47}$ Armus, op. cit. (note 13), 533.

48 Rodríguez, op. cit. (note 24), 177 f.

${ }^{49}$ Meik, op. cit. (note 13), 121.

${ }^{50}$ Penna, op. cit. (note 20), 72.

${ }^{51} \mathrm{Ibid}$.

${ }^{52}$ Ibid.
} 


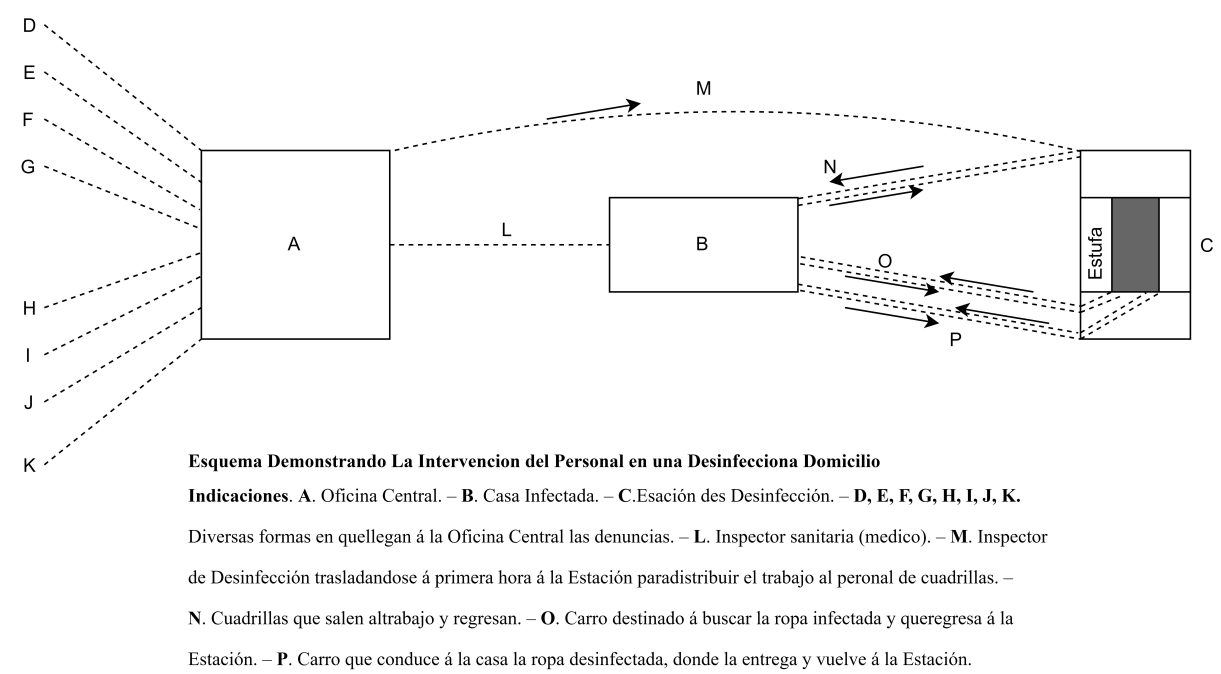

Figure 1: Scheme to present the brigade's interventions in disinfecting a private home. Drawn after the original in José Penna, La Administración Sanitaria y Asistencia Pública de la Ciudad de Buenos Aires (Buenos Aires: Imp. G. Kraft, 1910), 132.

According to Alvarez, this system of disinfection was publicly considered capable of returning places in which infections had occurred back to a healthy state. It encouraged trust in the health authorities and led rarely to resistance or objections. When the brigade disinfected a house, these practices not only aimed to clean the area of specific pathogens, but the brigades demonstrated to the public that traditional methods of cleaning and washing carried out by families in private were insufficient. Alvarez emphasises that the health authority did not only aim to ensure the health of the population, but they made sure these actions were impressed on the public memory. ${ }^{53}$

\section{The Crisis of Bubonic Plague in 1900}

By the end of the nineteenth century, Buenos Aires was considered one of the cleanest cities in Latin America. In 1899, Luis Agote, the city's bacteriologist, assumed Buenos Aires had replaced even the lauded status of London as the most hygienic urban location in the world. ${ }^{54}$ But, as Agote admitted later, all the cleanliness did not prevent the eventual arrival of bubonic plague in the city. Echenberg points out that because Buenos Aires was seen by its own elites as one of the healthiest cities in the world in 1900, the 'arrival of bubonic plague came as a great shock'. ${ }^{55}$

The appearance of this epidemic, first in Rosario and later in Buenos Aires, allowed the medical elites to drastically shift the direction of public health services in the Argentinian capital. The traditional quarantine of both cities, as practised in Portugal's Porto in the year before, seemed impractical. A quarantine posed logistical challenges to a large city and exceeded the government's capacities. Moreover, the ensuing commercial interruption

\footnotetext{
53 Alvarez, op. cit. (note 13).

54 Agote and Medina, op. cit. (note 14), 105.

55 Echenberg, op. cit. (note 14), 137.
} 
was considered too costly, given the relatively low numbers of infections and lethal cases. ${ }^{56}$ Instead, as in a number of other ports in the same period, the outbreak of plague encouraged public health officials to radicalise and extend fumigation practices. Like many other port cities, Buenos Aires had already invested in the installation and development of a sophisticated disinfection station at the port with adequate capacity to accommodate the growing volume of maritime trade. ${ }^{57}$ Over the first decade of the twentieth century and in the aftermath of plague outbreaks, these precise routines, developed at ports and disinfection stations, were mobilised and applied across the urban landscape of Buenos Aires to sustain the vision of a disinfected capital, to establish the hazardous presence of an infectious terrain and to turn the brigade's activities into a coordinated practice of prevention.

Plague in the south of Latin America broke out initially in Asuncion, Paraguay's capital, in April 1899. The Centauro, a ship under Argentinian flag bringing rice from Bombay via Rotterdam, provoked suspicion. Although it initially disembarked large portions of its cargo in Montevideo, Uruguay, the outbreak occurred later in Asuncion, where sanitary measures and surveillance practices were thought mediocre compared to the standards established on the other site of the La Plata river. An anonymous author in the Argentinian medical weekly, La Semana Medica, articulated a sentiment many medical professionals in Argentina shared at the time: Paraguay simply lacked the necessary sanitary measures that would have prevented the outbreak in the first place.

While the country had been following agreed quarantine regulations of ten-day detention, Paraguay's disinfection capacities were considered inadequate. The disinfection machine available to the port authorities in Asuncion, the author reported, was barely large enough to disinfect the personal belongings of a single person, and failed systematically to achieve the sanitary hygiene required to keep plague at bay. Instead, proper fumigation of the Centauro with sulphuric gases would probably have kept Asuncion, and also Argentina, safe. This practice was already in place in Brazil and Argentina's ports. ${ }^{58}$

Immediately after reports of plague in Paraguay reached Buenos Aires, Argentina's medical elite offered its assistance to contain the outbreak. But nonetheless, plague ravaged Asuncion from May 1899 to February 1900 and left 114 people dead. As a result of intense trade relations between Asuncion and Argentina, cases of bubonic plague were eventually recorded in the industrial Argentinian port city of Rosario. The first patient in Rosario was officially registered on 18 January 1900, but per Agote's report, the epidemic had probably begun in September 1899. In Rosario, the epidemic quickly escalated to approximately 700 cases, of which 248 proved fatal. ${ }^{59}$

Malbran was put in charge of the medical commission sent to Rosario, and declared that poor local conditions had fostered the outbreak. As clinical diagnosis and bacteriological findings were unambiguous, the remaining question for Argentina's 'higienistas' was how and why plague had found its way into the country, despite the nation's perceived sanitary superiority. Malbran's preliminary conclusions reinstated the significance of a system of observation and prophylactic intervention in order to prevent the diffusion of the epidemic

\footnotetext{
${ }^{56}$ Maria Antónia Pires de Almeida, 'Epidemics in the News: Health and Hygiene in the Press in Periods of Crisis', Public Understanding of Science, 22, 7 (2013), 886-902.

57 Carlos Malbran, Apuntes sobre Salud Publica (Buenos Aires: n.a., 1931).

58 Anon., 'Otra vez la peste del Paraguay y el Departemento Nacional de Higiene', La Semana Medica, 7, 26 (1900), 388.

59 Agote and Medina, op. cit. (note 14), 101.
} 
beyond the port city north of the capital. In addition to reporting suspicious cases and isolation of patients as well as their families, future attention should be given to sufficient disinfection of houses and affected neighbourhoods. While it was imperative for boats' cargo to be disinfected thoroughly with sulphuric gases, Malbran demanded that boats had to be freed of rats by any means available before goods could be unloaded onto Argentinian soil. ${ }^{60}$

By December 1899, plague had probably already arrived in the capital. Although initially registered as a case of severe influenza, Agote declared the fate of the grain dealer 'J.M.' and identified him as the first appearance of plague in Buenos Aires. It took until January for the epidemic to be officially announced, and a further few months until May for the scourge to have peaked, though it caused a rather low death toll just short of one hundred fatalities. The official response to the epidemic in Buenos Aires was in principle the same as in Rosario: isolation hospitals were set up, workers were sent home and affected grain depots and industrial areas were closed for extensive disinfection and fumigation. As Echenberg has noted, free public baths were opened and end-of-day garbage collections were started. ${ }^{61}$

But as Agote, Medina and Penna stressed, the emergence of plague was also indicative of a drastic failure of previously celebrated sanitary measures. Agote and Medina attributed the failed prevention of the epidemic to the aetiological complexities of plague. While yellow fever and cholera appeared to have been under control due to disinfection measures - both diseases had largely disappeared from the capital throughout the $1890 \mathrm{~s}$ - plague eluded the same framework and posed a set of new problems with regard to the introduction of epidemics from abroad. Where methods of maritime sanitation were previously focused on a human carrier, and his or her immediate surroundings, plague shifted attention to the epidemic environment: the ecology of the bacteria responsible for the disease. 'The epidemic milieu', Agote and Medina wrote, 'is the result of many factors, some large, some rather small, which maintain a perfect balance. ${ }^{, 62}$ The lesson of plague was to approach this milieu in all its complexity, rather than narrowly concentrate on an individual factor or a single cause. The challenge for sanitary prevention was therefore how to disrupt the balance of such an epidemic system in the most effective and efficient way. Moreover, the question emerged whether plague might indeed be an epidemic that was caused by factors within the city and if modes of prevention should move beyond the protection against the disease's import at the harbour.

Here the rat began to enter the epistemology of Argentinian epidemiology. Already by 1899 a few publications in La Semana Medica had pointed to the growing significance of rats in outbreaks of bubonic plague in India, and in Porto at that time. The Pasteurian PaulLouis Simond had published his research in 1898 on rats as a possible principal vector, a proposition which found increasing recognition in the field, but would not be fullyaccepted until around $1905 .{ }^{63}$ Described as an agent of contamination and infection, the rat was usually seen in Buenos Aires as an important concern regarding the import of the disease. Netter, a local physician, assumed in 1899 the significance of the rat as a vector but subordinated by the 'contagio directo', from human to human, yet still considered plague's

\footnotetext{
${ }^{60}$ Carlos Malbran, 'La Peste Del Rosario', La Semana Medica, 7,7 (1900), 91-4.

${ }^{61}$ Echenberg, op. cit. (note 14), 143.

62 Agote and Medina, op. cit. (note 14), 77.

${ }^{63}$ Paul-Louis Simond, 'La Propagation de La Peste', Annales de l'Institut Pasteur, 62 (1898), 80-98.
} 
bacterial cause to be transmitted on the surface of cargo, merchandise and foodstuffs. ${ }^{64}$ Decoud, also writing in Argentina in 1899, largely agreed with the argument of Simond, and afforded a vague position to the rat as an infectious influence, a possible carrier of the pathogen in the holds of ships. ${ }^{65}$

The rat was mostly seen as a problem for the port authorities. In the immediate aftermath of the outbreak, the rat remained associated with the introduction of plague through the harbour. The regulations established in 1892 to protect Argentinian ports against 'exotic diseases' were seen as unreliable as they had failed to integrate the transmission of plague through rats. Agote and Medina stressed in 1901 that a response was needed that would cover both the transmission of plague via rodents, as well as possible transmission through cargo. 'Dr Simond strongly argued that the rat is the main agent for the spread of plague', they wrote, 'but recognises the importance of the role played by infested merchandise which would in turn contaminate the rodents, which would thus become the main factors in the expansion of epidemics. ${ }^{66}$ Citing the definition of quarantine from the 1897 Venice conference, they argued that, although the evidence for infested merchandise and rats was lacking, to ignore this hypothesis would leave vast pathways of possible transmission open. 'Neither the isolation of the sick, nor the disinfection of the vessel under the prescribed conditions, would have caused the death of the rodents, the principal vehicle of the disease', they added. ${ }^{67}$ The conclusion should therefore be a thorough disinfection, supervised by sanitary officers and independent physicians, on every vessel entering from infected countries that could possibly be carrying infested merchandise or infected rats.

Even though the consideration of rats began to suggest that plague might indeed not only be a threat of importation, the city's first reaction was the improvement of the port's disinfection equipment and in 1900 a fully equipped 'Estacion Sanitaria' was planned. These considerations, Malbran remembered in a short essay from 1931, motivated his first actions in the 'Direccion Nacional de Higiene', as he ordered not only the erection of the sanitation station but abolished effectively all traditional quarantine. ${ }^{68}$ The practice of involuntary detention had damaging repercussions for both transnational and national trade, and had failed to protect Argentina from foreign diseases, plague most notably. Instead, effective protection against epidemics from maritime trade should be set on firm scientific grounds. The new station, finished by 1906, was built complete with a library and a 'Museo Sanitario', Sanitary Museum, to train new officers. Until the station was finished, floating fumigation devices were equipped with a Clayton machine and used to carry out disinfection on arriving and departing ships. They exterminated microbes on surfaces and in the merchandise, but also provided an effective weapon against rats and insects to protect Buenos Aires from further import of infectious diseases. ${ }^{69}$

In the aftermath of the 1900 plague outbreak in Buenos Aires, modern sulphurbased sanitation equipment became quickly standardised in the city's harbour. It was only a matter of time until considerations around the rat as a possible vector of plague in vessels were extended to the many rats populating the streets and burrows of the capital. And as suspicion grew that the city's rats were indeed implicated in the dynamic

${ }^{64}$ M. Netter, 'La Peste durante esos ultimos anos. Sintomas - Marcha - Diagnostico', La Semana Medica, 6, 46 (1899), 423-8.

65 Diogenes Decoud, 'La Fiebre Bubonica. Mecanismo del contagio', La Semana Medica, 6, 46 (1899), 429-30.

66 Agote and Medina, op. cit. (note 14), 211.

${ }^{67}$ Ibid., 215.

${ }^{68}$ Malbran, op. cit. (note 57).

${ }^{69}$ Malbran, op. cit. (note 60), $25 \mathrm{f}$. 
of plague in Buenos Aires, so grew the conviction that existing urban measures of prevention and intervention were in need of critical upgrades. Over the following years, two decisive changes were made. First, with the acquisition of the Aparato Marot in 1906, the technological advantages of modernised sulphur-based disinfection machines were introduced into the work of the sanitary brigades. Second, this acquisition was accompanied by a conceptual shift, as the brigade's work was less and less seen as a mode of intervention in the aftermath of outbreaks and infections, but would instead become a practice of prevention that aimed to establish 'general prophylaxis'.

\section{The Aparato Marot, the Rat and the City}

By 1900, the Clayton machine had become a globally standardised technology in sulphurbased maritime sanitation. This method of industrious eradication for the purpose of maritime sanitation had originated in the second half of the nineteenth century as a result of the ongoing yellow fever crisis in New Orleans. ${ }^{70}$ The failure of traditional quarantine methods, combined with the injurious consequences for trade with Latin American markets, led the Louisiana board of health to develop an elaborate disinfection system that could free boats and cargo arriving on the Mississippi delta from pathogens and infectious, or, rather, suspicious, vectors. ${ }^{71}$ During the first years of the twentieth century, machines like the Clayton, which protected Buenos Aires' port, were adapted, developed and would go on to provide a blueprint for larger, more efficient and lethal machines, such as the Aparato Marot.

The consideration of using machines on the streets of Buenos Aires, originally developed for sanitation in the ports, was accompanied, perhaps encouraged, by a decisive shift in the identification of the cause for plague outbreaks in the capital. Rather than repeatedly imported by sea trade, plague came to be considered to silently hide within the fabric of the city. After the 1900 outbreak, the rodent and its burrows were quickly suspected by the 'higienistas' to permanently harbour plague. Agote and Medina had already discussed in their 1901 report that plague was perhaps not always imported but could have been sustained by non-human vectors within the city. ${ }^{72}$ Penna argued in the same year in a contribution on the aetiology of bubonic plague in La Semana Medica that, while proof was still lacking, the rat should be considered the most likely source of the epidemic and its fluctuations in the capital. ${ }^{73}$ From 1901 onwards, the 'higienistas' shifted the government's epidemiological focus from the entry of plague from foreign countries, to the conditions under which this and other diseases might nest within the fabrics of the urban infrastructure. To address the newfound view, that the city and its rats could harbour disease, the sanitary brigades were reorganised and 'the personnel was increased', Penna wrote, 'to extend the capacities of home disinfection against the multiplication of transmissible diseases'. ${ }^{74}$

\footnotetext{
${ }^{70}$ William Coleman, Yellow Fever in the North: The Methods of Early Epidemiology (Madison: University of Wisconsin Press, 1987); Margaret Humphreys, Yellow Fever and the South (Baltimore: Johns Hopkins University Press, 1999).

${ }^{71}$ Gordon Gillson, Louisiana State Board of Health: The Progressive Years (New Orleans: Louisiana State Board of Health, 1976), 18.

72 Agote and Medina, op. cit. (note 14), 99.

73 José Penna, 'Consideraciones sobre la etiologia de la peste', La Semana Medica, 8, 28 (1901), 420.

${ }^{74}$ Penna, op. cit. (note 20), 150.
} 
For the disinfection brigades that patrolled private homes and warehouses in Buenos Aires after 1888, the steam-based sterilisation of goods and fabrics had long been the most important practice. Additionally, the brigades usually used sprayers delivering dichloride solutions to wash walls and floors. Burning sulphur was practiced in a less regulated manner than the majority of other sanitary routines and had been guided by vague and outdated assumptions about the cleansing effects of the fumes, which were never tested for efficacy. While the sulphur's principal target had been the disinfection of private homes, it was also speculated to work on 'miasma, the effluvia and emanations from fermentation or rotting organic material'. ${ }^{75}$ As this disinfection practice was carried out poorly, Penna complained in 1910, it was merely effective against pathogens, and acted predominantly 'on the frightened imagination of the people' ${ }^{76}$ Commonly seen as a practice of cleaning the air from bad odours, Penna had observed a regular fumigation build-up as sulphurous fires filled with 'sinister gleams the sad and sombre picture of the capital' ${ }^{77}$ But the extensive fumigation of houses affected by cholera or yellow fever using sulphur, chlorine and nitrous vapours was not based on any sound scientific research and did not, after all, prevent the outbreak of plague. The reason was to be found, so Penna argued, not only in the poorly executed fumigation, but also in a missing systematisation of the brigade's intervention, which only responded to individual cases and outbreaks instead of providing a large-scale service of preventing disease across the entire city.

Since the 1890s the sanitary administration had steadily increased its disinfection activities. In 1889 the service had only disinfected 1458 houses after infections had occurred, by 1895 this number had increased to 4542 and by 1905 disinfection teams visited more than 7000 dwellings per year to carry out their work. ${ }^{78}$ A mobile disinfection stove was purchased in 1895 to support disinfection of premises in the north. In 1901 and 1904 both disinfection stations were equipped with a so-called 'dehaitre' system, which enabled disinfection with formalin and formaldehyde. Once Penna took over the Asistencia Pública in 1906, his steadfast microbiological conviction, coupled with his unique appreciation of the disease's terrain, moved to the centre of his unique version of a 'Utopia del Higienismo'. ${ }^{79}$

Within a few months the sanitary service saw a major expansion of fumigation equipment designed to mobilise technological appliances and to bring the full scope of disinfection advantages directly to the benefit of the entire city. Three new disinfection stations were opened and equipped with twelve sterilisation ovens, thirty-six new 'Geneste-Herscher' sprayers were bought to maximise the outreach of the sanitary brigades. But, most importantly, from now on the sanitary campaigns could also rely on a brand-new fumigation machine. Under Penna, and with the support of the new technology, the purpose of the brigades shifted from returning infected premises into a healthy state to the preventive disinfection of the entire city, and thus gave way to develop the ambitious goal of a total deratisation of Buenos Aires. Not only did the Aparato Marot enable

\footnotetext{
75 Ibid., 142.

76 Ibid.

77 Ibid.

${ }^{78}$ Meik, op. cit. (note 13), 15. Archive of the City of Buenos Aires: 'Memoria de la Intendencia Municipal de la Ciudad de Buenos Aires correspondiente a 1889, presentada al H. Concejo Deliberante por el Intendente Seeber' (Buenos Aires, 1891), 129; 'Memoria Presentada al Concejo Deliberante por el Intendente Municipal Señor Emilio V. Bunge; Año 1895' (Buenos Aires, 1896), 60; 'Memoria de la Intendencia Municipal; año 1905' (Buenos Aires, 1906), 75.

${ }^{79}$ Kohl, op. cit. (note 8), 73.
} 
this significant shift of the brigade's purpose, it also reinstated the popular and common practice of sulphurisation as a modern technology of disinfection and disinfestation.

Initially, and on advice from Penna, the city bought a pair of Model No. 2 machines, and four of the larger Model No. 4, two of which were mounted on automobiles while the others rested on horse carriages. For Penna, with the acquisition of the Aparato Marot, the disinfection brigades were for the first time able to fulfil their envisioned role to the full extent. ${ }^{80}$ As the total deratisation of premises became suddenly possible, Penna gave the brigades a new purpose as a means of protection and reshaped their practices as a mode of prevention. The machine's design provided quick and mobile interventions everywhere in the city, and, as Penna emphasises repeatedly, its mode of disinfection was now reliable as it was set on solid scientific facts. When used correctly, the Sulfurozador was capable of delivering 'perfection' in the destruction of everything that could lead to infectious disease: pathogens, insects and rodents. ${ }^{81}$ Pumping this novel gaseous mixture, an electrified version of sulphur dioxide, into houses, restaurants and warehouses promised rapid and thorough destruction of pathogens, insects and rodents without harm to organic materials or lasting damage to furniture. There was no reason to apply these outstanding disinfection capacities only to those premises in which diseases had occurred, given the likelihood of rats spreading germs all over the capital.

The Marot had been built by Rene Marot in France with the explicit aim to improve the rat-killing capacities of fumigation with sulphur dioxide. ${ }^{82}$ These disinfestation capacities were achieved through a specific design. The machine could deliver twenty-five cubic metres of gas per minute. Other than the Clayton machine's reliance on a furnace, it used liquefied gas, stored in pressurised containers, which was expanded within a pipe heated by Bunsen burners that were attached to a pressurised oil heating system. The heating prevented the tubes from freezing due to the drop in temperature during the expansion of the gas. From here, the gas passed through a special device that electrified it and thus provided an extended lethal capacity. The gas was then introduced into the room through a fan that also extracted the air from the fumigated enclosure. The fan, as well as the electrifying device, was operated by a small combustion engine. ${ }^{83}$ This ingenious addition, which 'ozonofied' the gas, gave the machine its colloquial Argentinian name 'Sulfurozador'.

The electrified sulphuric gas had acquired the name 'Gaz Marot' in France. Electrification, so the theory went, reduced the hydrogen in the gas, which might have contributed to fast dissemination as the gas bound itself more easily to existing moisture in the fumigated room. This procedure supposedly doubled the efficacy of the compound against rodents when compared to the Clayton. Experiments conducted in Paris by Wurtz and Bonjean showed that with twenty grams of sulphur used to make conventional sulphur dioxide, rats died after forty-eight minutes of exposure, while the same amount of Gaz Marot proved fatal after only twenty-four minutes. Furthermore, Gaz Marot showed similar lethal qualities to microbes as sulphur dioxide, and was superior in its preservation of by-standing objects, goods and foodstuffs. The Comité Central des Armateurs de

\footnotetext{
${ }^{80}$ Penna, op. cit. (note 20), 159.

${ }^{81}$ Ibid., 168.

82 A. Chantemesse, 'Rapport sur les Experiences de Destruction des Rats a Bord des Navires au Moyen de L'Anhydride Sulfureux Liquide', in Mininstere de l'Interieur (ed.), Recueil des actes officiels et documents intéressant l'hygiène publique travaux du comite consultatif d'hygiene publique (Paris, 1905), 191-214; Gabriel Magny, Rats et peste (Paris: Paris: Bonvalet-Jouve, 1907).

83 Magny, ibid., $98 \mathrm{f}$.
} 
France, the organisation of ship-owners in France, officially preferred the new Gaz Marot over the Clayton machine after 1905 as it proved efficient against both rats and vermin as well as harmless to valuable merchandise. ${ }^{84}$

Penna also declared the Marot machine to be advantageous compared to the outdated Clayton machine. The pressure released by the Marot was constant rather than shifting as with the Clayton. The amount of gas required for disinfection of warehouses, tanks, railway stations, docks and barracks was lower and the Marot required manageable volumes of liquid sulphuric acid, and the pressurised compound could be easily stored in large quantities. Furthermore, the ozone effect stemming from the electrification of the gas drastically improved its qualities as insecticide and pesticide. ${ }^{85}$ Penna referred to this effect as a stirring of the atmosphere, 'una agitacion de su atmosfera' ${ }^{86}$ This prominent feature of the machine was essential for Penna to promise the effective asphyxiation of rodents in every aspect of the urban environment. Where Clayton machines relied on the considerable pressure of closed spaces such as the holds of vessels to achieve similar results, the Marot's technical capacity enabled Penna to reinstate his vision of an entire city without pathogens. Previously a vision that had been a privilege of the old sanitarian's miasmatic views, Penna could reinvent their popular utopia now with the support of modern science and engineering.

Penna further pointed out that the major benefit of fumigation with the Marot was reaching far beyond the problem of rats. Its versatile efficacy could be used against any known pathogen that caused infectious diseases in Buenos Aires at the time:

The applications of Marot gas are multiple. It will be used for the extermination of fleas, bedbugs, lice, mosquitoes, etc., which can be the propagators of some diseases: for the destruction of insects such as worms, butterflies, moths, etc. [...] Also, it not only possesses these indicated properties, but it is also capable of destroying the microbes of cholera, plague, diphtheria, typhoid, etc. ${ }^{87}$

As the French had already shown, the Marot was the best machine for maritime hygiene and port sanitation in 1905; but, in the following year, Penna conducted a number of experiments to demonstrate to the world that the machine was equally fitted for disinfecting mills, cereal and grain deposits, forages, railway stations, factories and, of course, the private home. Penna tested the machine's applicability to a wide range of scenarios, objects and pathogenic agents. The detailed report from 15 June 1907, sent to the government of Argentina, is built around the consideration of rats. In the experiment, rodents were placed in cages of varying heights, resembling many of their known habitations across the city. Furthermore, Penna added mosquitoes in nets, cultures of bacteria on agar, infectious substances and foodstuffs to observe the impact of the Gaz Marot. The test objects were exposed to the gas for half an hour and, in short, Penna could demonstrate the successful destruction of all possible vectors, while foodstuff, clothes and valuables remained unharmed. ${ }^{88}$

Thus, the Asistencia Pública was believed to have enabled a method for enduring safety against epidemic outbreaks and provided a new level of hygienic modernity in Latin

\footnotetext{
84 There were a number of competing machines in place at the time. A comprehensive comparison of the machines in their functionality, efficiency and economic values is given by J. Chaine in 1932: J. Chaine, 'Raport sur la destruction des rats', Deuxième Conférence internationale et congrès colonial du rat et de la peste: Paris, 7-12 octobre 1931/documents réunis et publiés par. . . Gabriel Petit (Paris: Vigot, 1932), 453-463.

85 Penna, op. cit. (note 20), 161.

${ }^{86}$ Ibid., 168.

87 Ibid., 170.

${ }^{88}$ Penna, op. cit. (note 20), 173-93.
} 
America, perhaps the world. If applied in the right way, Penna wrote, the machine would allow a mode of prophylaxis to succeed and eventually force all infectious diseases to disappear from the landscape of Buenos Aires. ${ }^{89}$ Fuelled by the extensive technological capacities of the Sulfurozador, experimentally tested as a recipe for total disinfection, Penna reinvigorated the old hygienic utopianism. But, now, the disinfection machine took on the practical as well as the symbolic place of the old sanitary campaigns, enabling the vision of a future without disease, and bringing back the terrain of the city as the central source of concerns. If the new apparatus was used rigorously, if the distribution of fumigating brigades across the city were wide enough and if a number of additional practices and conventions were applied carefully, Penna argued in 1910, the city would eventually see a future free from epidemics. ${ }^{90}$

In practice, Penna ordered over 10000 precautionary disinfections of private premises in the first year of his directorship of the Asistencia Pública. ${ }^{91} \mathrm{He}$ extended orders to use the Aparato Marot to disinfect tram carriages and designed a concerted campaign of deratisation, which began at the harbour and should eventually cover the entire capital. ${ }^{92}$ By 1908, Penna boasted, 28101 houses had received treatment from the new machine. ${ }^{93}$

Also in 1908, a paper manual to instruct the military laid out the elements of the new 'Higiene Colectiva', Collective Hygiene, that was driving Penna's vision. The manual gave prominence to individual hygiene and household cleanliness, and discussed how the risks of contamination and infection remained the responsibility of the members of the community. But '[s]trict individual hygiene is therefore to be accompanied by an irreproachable collective hygiene', states the manual, 'which must constantly improve the sanitary state of the environment'. ${ }^{94}$ In the manual, the Aparato Marot was seen as the primary and principled weapon against the most powerful hygienic enemy of the state within its own boundaries: the rat. ${ }^{95}$ When applied and used appropriately and extensively, not only would rats disappear, but any possible cause for infection would eventually vanish. Collective hygiene returned as a shared responsibility for a nation free from disease, but this time it was enabled by the state's modern and capable practice of comprehensive disinfection with the Aparato Marot.

As Pedro Rivero, head of the disinfection and sanitation service of Buenos Aires, writes in 1911, the transformation of the sanitary brigades under Penna had led to wideranging changes. Within five years Penna had trained and employed ninety new health assistants and ten new foremen. He had raised the budget of the brigades, equipped them with innovative and essential machines and thus prepared the Asistencia Pública to embark on what Rivero articulated as a courageous vision of the total 'deratisation' of Buenos Aires. Building on the legacy of Penna, Rivero was convinced that '[1]os aparatos deraticidas Marot' had fuelled the hope to rid the city of the most important diseasecarrying adversary. It had shown how the once utopian idea of deratisation had begun to shape the reality of the capital. ${ }^{96}$

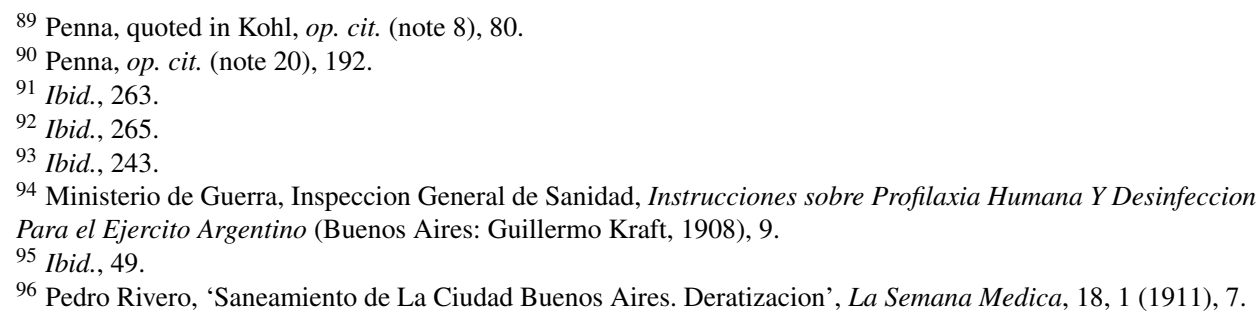


Rivero celebrated the introduction of the Aparato Marot as the technological solution for an otherwise unsurmountable challenge. Trappings, poison campaigns and even specially trained dogs - 'perro ratenero' - had always failed to penetrate those spaces under floorboards, in basements and between houses, in which rats continued to hide. It was the fleet of Marot machines through which the idea of a full deratisation became feasible, as its gas could penetrate every hiding spot above and below the ground. After all, the Aparato allowed the Asistencia Pública to increase their activities far beyond the scope of the traditional disinfection brigades, bringing about an entirely new way of precautionary and preventive disinfection. Describing the success of the new campaign so far, Rivero reports that by December 1909 more than 1816 blocks of the city had been disinfected. A map that he published as the service's director in 1911 shows all disinfected blocks painted black. The map, and Rivero's celebratory report, bears witness to the rapid progress of the new systematic way in which disinfection brigades had already covered one-third of the terrain of Buenos Aires (see Figure 2).

With the theoretical, experimental and practical application of the Aparato Marot, the machine encapsulated the key principles of Argentina's hygienic legacy to reformulate them alongside modernised perspectives regarding diseases and their ecologies. The traditional practice of burning sulphur, applied throughout the nineteenth century in the campaigns against bad odours and the stench of latrines, had been adapted in a highly sophisticated practice, mobilising laboratory science and pragmatic approaches to the niches and rodent vectors of pathogens. With the installation of the Marot, focus shifted from removing smell and stench through sanitary campaigns to the lethal efficacy of a gas in variable environments.

But the Marot also symbolised the urban application of a procedure that was initially developed in the context of international efforts of maritime sanitation. Rigorous implementation of the procedure into the capital's terrain symbolised the extensive political authority of the new public health programmes, driven again by a utopia of a disease-free capital. The Aparato Marot thus became an instrument not only of disease prevention, but also symbolised the reinvigorated state's intrusive capacity to maintain the cleanliness of its citizen's homes. After 1906, as Armus recalls, the ubiquitous presence of disinfection brigades under the direction of Penna led to an 'army of hygiene and prevention' invading the urban landscape, demonstrating visibly the established links between public health, technology and progress. In their uniforms and equipped with the powerful new machines, the brigades appeared as a 'strange force of occupation'. (See Figure 3.) ${ }^{97}$

The Aparato Marot served as an instrument of hygienic and cultural calibration for Buenos Aires to keep its streets as clean as its inhabitants' homes, while sustaining the city's status in what Penna has called its 'perpetual epidemic state' ${ }^{98}$ Finally, the Sulfurozador was an essential element of the modernisation of the hygienic heritage of the capital. With a prominent, but not exclusive, focus on plague and the rat, it put newfound disease aetiologies and theories about their urban hiding grounds on display to the public, while similarly demonstrating the government's masterful control over the city's terrain. ${ }^{99}$

\footnotetext{
97 Armus, op. cit. (note 13), 535.

98 Penna, op. cit. (note 20), 119.

99 Amador, op. cit. (note 4), 8.
} 


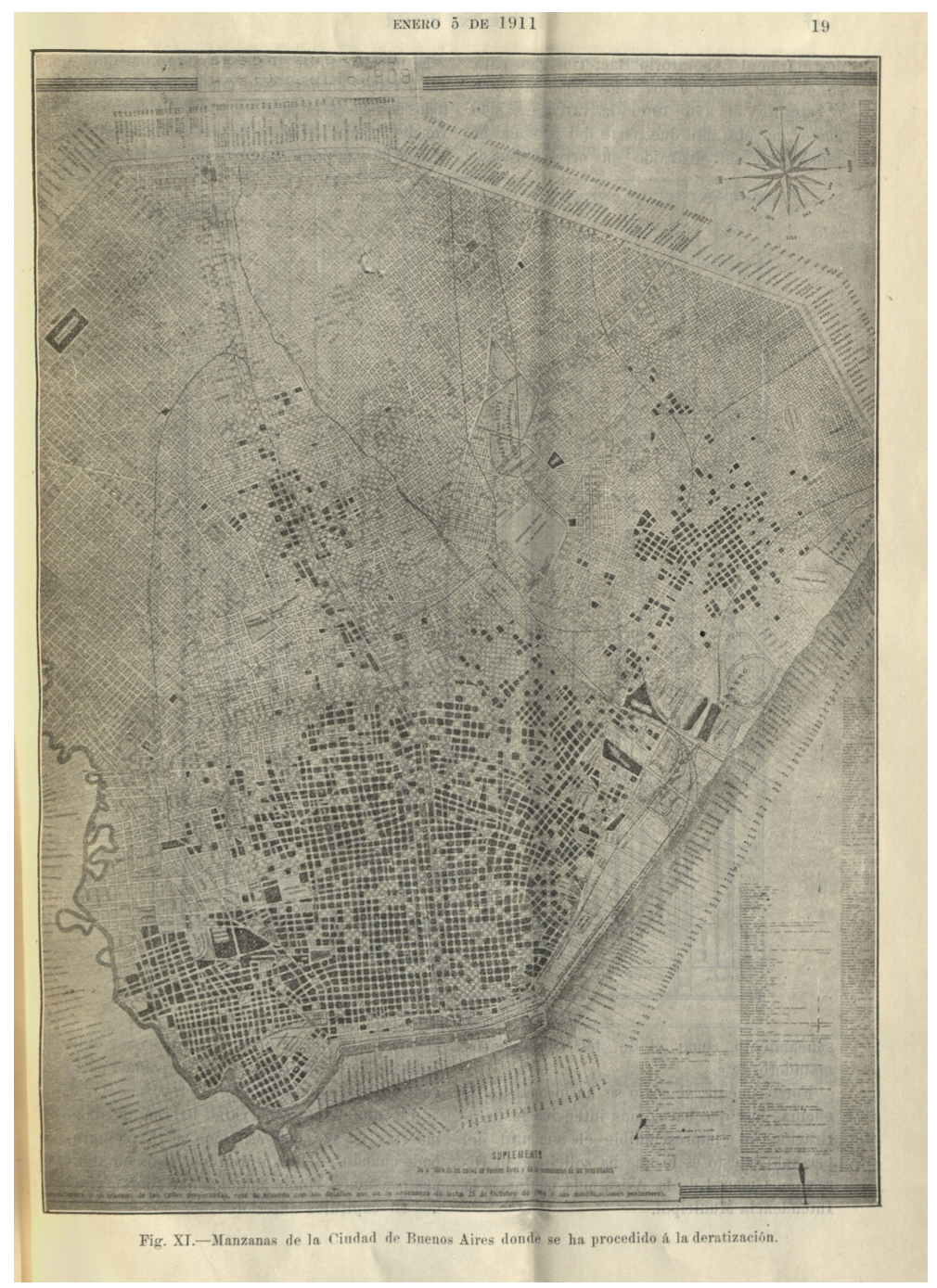

Figure 2: Map of the progress of deratisation campaigns in Buenos Aires. Source: Pedro Rivero, 'Saneamiento de La Ciudad Buenos Aires. Deratizacion', La Semana Medica, 18, 1 (1911), 19. Courtesy of the New York Academy of Medicine Library.

\section{Conclusion: A Theory and Practice of General Prophylaxis}

The purpose of this article has been to re-introduce the particulars of a machine and its technological as well as its metaphorical capacities into the history of the hygienic movement of early twentieth-century Argentina. Buenos Aires was certainly not the only place in which fumigation was introduced as a scientific method of urban disinfection. For example, Amador has pointed to the pivotal role fumigation played in the American intervention in Cuba in the same period. There, the sophisticated practice of the disinfection machines was not only seen as a symbolic demonstration of the American forces' technological superiority, it also supposedly rejected tired conceptions 


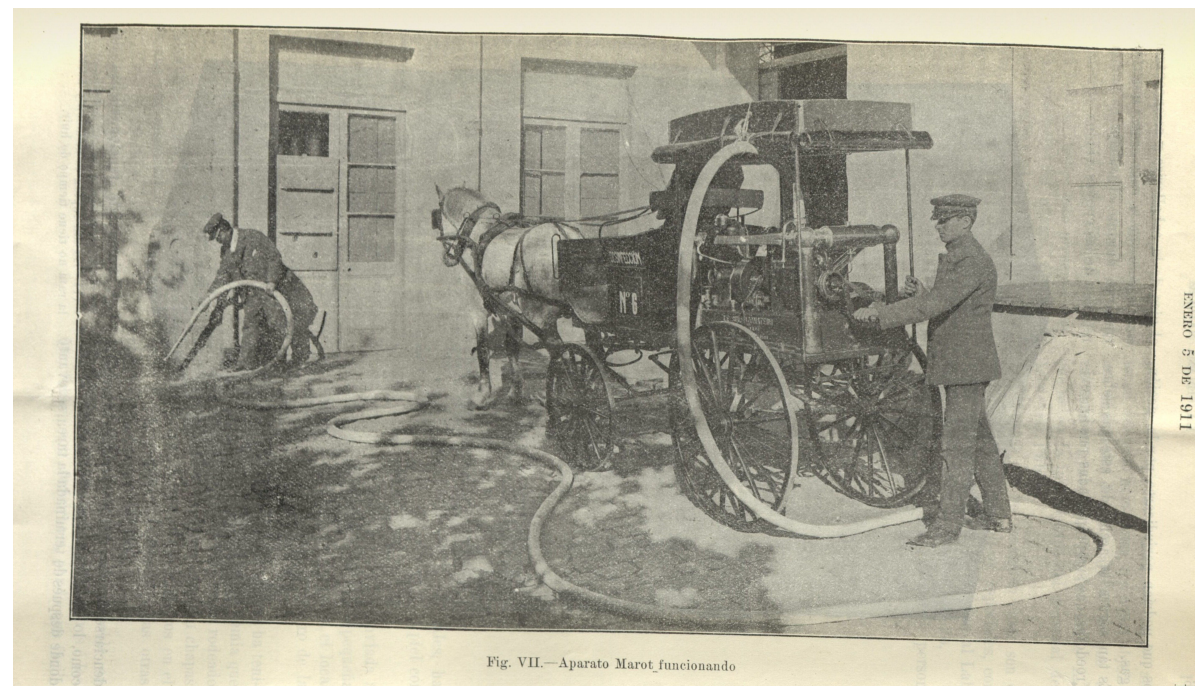

Figure 3: Aparato Marot_funcionando (working). Source: Pedro Rivero, 'Saneamiento de La Ciudad Buenos Aires. Deratizacion', La Semana Medica 18, 1, (1911), 15. Courtesy of the New York Academy of Medicine Library.

of racial inferiority and degeneration as causes of diseases. The spectacular fumigation of streets, houses and sewers in Cuba demonstrated a newfound mastery of the tropical environment. ${ }^{100}$ Rio de Janeiro equipped its own sanitary brigades with mobilised Clayton machines, while the same apparatus was used across the US for comprehensive disinfection of sewage systems. ${ }^{101}$ Using sulphur-based disinfection machines for urban sanitation was, from the early years of the twentieth century, in the shadow of the plague pandemic, a common sight in many port cities around the world. ${ }^{102}$ It is difficult to grasp the success of such machines and their associated campaigns. Most cities gave up on their usage, given the uncertainty regarding their efficacy and the high level of intrusiveness, which sparked resistance, for example, in San Francisco and New Orleans.

It was peculiar to Buenos Aires that the apparatus seems to have encapsulated and catalysed a renewed hygienic enthusiasm for the total disinfection of the city's terrain. I have presented this as a reinvigorated vision of Rawson's 1870s hygienic utopia of a new state free from disease. Penna's technological translation of this vision was realised through the Aparato Marot. A modernised machine, delivering laboratory-developed sulphur-based disinfection had encouraged a new doctrine of 'general prophylaxis', which indeed continued far into the twentieth century.

In 1912 the 'theory and practice' of disinfection became the subject of yet another extensive manual of Argentina's Department of the Interior. Building on a long Argentinian tradition of personal and public hygienic cleanliness, the manual distinguished

100 Amador, op. cit. (note 4), $7 \mathrm{ff}$.

${ }^{101}$ Benchimol, op. cit. (note 7). J.J. Kinyoun, 'The Prophylaxis of Plague', Journal of the American Medical Association, XLII, 4 (1904), 232-9.

102 Echenberg, op. cit. (note 14). 
between two forms of 'profilaxia' ${ }^{103}$ On the one hand, special disinfection procedures were continued to deal with requirements that emerged from specific diseases. On the other hand, the main area of application for the 'Gaz Marot' was to achieve what the manual called 'general prophylaxis'. Given its tested and verified qualities, it was the only known substance to be effective against any known infectious agent, all suspicious nonhuman vectors, while at the same time being the least harmful to goods and the interior of premises. The Sulfurozador presented itself as the adequate technological solution, so stated the manual's author, to the nation's quest for total hygiene.

The Aparato Marot became a pillar of modernised urban sanitation in Buenos Aires, organised around the question of the rat. Metaphorically, the machine translated a principle of sanitation from the harbour to the streets and homes of Buenos Aires' citizens, establishing the changing acknowledgement of epidemic threats lurking within the urban society. But it was the technological novelty and chemical capacity that elevated the machine to embody the principle of general prophylaxis; a principle that attached itself to Rawson's and Wilde's nineteenth-century poetics of hygienic utopianism. The Sulfurozador was a spectacular machine that continued to act upon the imagination of Argentina's citizens, but it also enacted a newfound application of bacteriology beyond the laboratory. With the Marot, Penna could successfully modernise and rationalise the traditional sanitary practice of acting everywhere and anywhere against disease. His work consolidated principles of sanitation, prophylaxis and the responsible state; principles through which Emilio Coni envisioned later in 1919 the ideal Argentinian city for the twentieth century. ${ }^{104}$

The unique character of sanitary hygiene in Buenos Aires would come to permeate the first half of the twentieth century. Reports, pamphlets and publications continued the discussion of disinfection practices and contributed to the persistence of a hygienic modernity as a cornerstone of the young republic up to its reinvention under Peron. Disinfection in the name of sanitary improvement, intrusion into people's homes and warehouses and the imperturbable belief of a proto-culture of sanitation continued to structure the self-perception of Argentinian's capital. Improvement to the city's sanitary state also continued to be coupled to an imagined improvement in moral and social hygiene. This history of the urban introduction of fumigation machine must be read as a history of the social and technical engineering towards a modern state - a state imagined to be immune to threats harboured in both the port as well as in its citizens' private homes.

\footnotetext{
${ }^{103}$ Ministerio del Interior, Departamento Nacional de Higiene (ed.), Tecnica Teorico-Practica de La Desinfeccion (Buenos Aires: Guillermo Kraft, 1912).

${ }^{104}$ Armus, op. cit. (note 9), 125.
} 